\title{
Brain drain as a function of sustainable development in the Republic of Macedonia
}

\author{
Article history: \\ Received: 2 October 2017 \\ Sent for revision: 14 October 2017 \\ Received in revised form: 23 January 2018 \\ Accepted: 23 January 2018 \\ Available online: 20 March 2018
}

\begin{abstract}
The main aim of this paper is research on the phenomenon "brain drain", in the Republic of Macedonia and its impact on sustainable development. It occurs when a highly skilled, educated professionals permanently emigrates from a developing to a developed countries. The paper gives an overview of the current situation regarding the emigration of highly skilled individuals from our country and generally from the Balkans. In connection with this, we analyze how it affects the process of transition and the labor market in these countries comparing to the countries of the European Union. Research methodology was conducted by using detailed questionnaires, which were answered by students at several public and private Faculties in Macedonia. It can be concluded that the impact of brain drain on sustainable development in Republic of Macedonia and the current situation of brain drain in our country are alarming, so it deserves special attention. Applying measures to diminish the brain drain should be recognized as national perspective.
\end{abstract}

Keywords: brain drain, brain circulation, sustainable development, Macedonia

\footnotetext{
${ }^{1}$ Research Center for Energy and Sustainable Development, Macedonian Academy of Sciences and Arts, Skopje, Macedonia, vlado@manu.edu.mk

2 Research Center for Energy and Sustainable Development, Macedonian Academy of Sciences and Arts, Skopje, Macedonia
} 
Dinkovski V., Simoska M.S.: Brain drain as a function of sustainable development in...

\section{Odliv mozgova kao funkcija održivog razvoja u Republici Makedoniji}

Apstrakt: Glavni cilj ovog rada su istraživanja fenomena "Odliv Mozgova", u Republici Makedoniji, i njegov uticaj na održivi razvoj. To se dešava kada visoko kvalifikovani kadar, obrazovani profesionalci polako emigriraju iz zemlje u razvoju u razvijene zemlje. Rad daje pregled na stanje u vezi sa iseljavanjem visoko kvalifikovanih lica iz naše zemlje i generalno, sa Balkana. $U$ vezi sa ovim, analizira se kako to utiče na proces tranzicije i pazar radne snage u ovim zemljama u usporedbi sa Evropskom Unijom. Koristili smo deteljne upitnike, a odgovore smo dobili od student sa nekoliko drzavnih i privatnih fakulteta u Makedoniji. Može se zaključiti da uticaj odliva mozgova na održliv razvoj u Republici Makedoniji i situacija sa odlivom mozgova je alarmantna, pa zato i zaslužuje posebnu pažnju. Primena mere za smanjenje odliva treba se tretirati kako nacionalni prioritet.

Ključne reči: Odliv mozgova, održivi razvoj, obrazovani profesionalci.

\section{Introduction}

Brain drain has been defined by many as migration of skilled individuals within countries and abroad in search of usually better conditions of service and life. The main reasons for brain drain in our country are closely related to the current social and political living conditions in the region.

Brain-drain is one of the biggest challenges for the policy makers in the Republic of Macedonia. The problem is linked to loss of investments in human capital and creative work force. The data provided by the World Bank for the year 2005 pointed out that the emigration rate for tertiary educated citizens was $20.9 \%$. Between 1993 and 2002 an estimated loss of 12,000 to 15,000 young, educated, and highly skilled persons happened to Macedonia.

The IOM Country Profile for Macedonia says: "Over the past decade, the former Yugoslav Republic of Macedonia, like most of its neighbors in South East Europe, has suffered from brain drain, with a strong decline in the number of researchers throughout the 1990s. Between 1995 and 2000, for example, the number of scientists and engineers in research and development has decreased by over seventy percent (from 1,332 per million people to only 387) (IOM, 2007).

But the "brain drain" is no longer a phenomenon that applies only to developing countries. In some developed countries, experts are beginning to feel threatened by a number of workers from overseas because they now need to compete with migrants for their jobs. In fact, they should be worried 
Dinkovski V., Simoska M.S.: Brain drain as a function of sustainable development in...

because developed countries are moving their migration policies to specific and special recruitment to attract more qualified educated young professionals. Also, the top students go to these developed countries to learn, but are assimilated into the culture and lifestyle, and if they find a job they will never return to their home countries.

\subsection{The brain drain in the rest of the world}

In Europe the brain drain had taken two stages. The first was the migration of scientists from South East and East Europe to the Western Europe, and the second migration is from Western Europe to the USA. In order to stop the brain drain, the EC launched the so-called Blue-card initiative. It is important to mention that the EU is concerned about the impact of foreign cultures and the environment, so that the EU imposed strict rules to regulate the flow of immigrants (Mahroum, 2001).

The countries in the Middle East also suffer from the phenomenon of brain drain. The lack of some basic conditions and services cause mass migration from these living places. Dictatorship, terrorism, violence are the main reasons for the increased outflow and problems in the development of this region (Horvat, 2004).

Africa most of all suffers from the brain drain, mostly due to high poverty and weak economies. Based on the research, Ethiopia has lost $75 \%$ of young professionals in the period 1980-1991. In same basket with Ethiopia can be placed Kenya and Nigeria in which there has been a large percentage of brain drain (Coombes, 2005).

Unemployment, overcrowding and corrupt political systems are the main reasons for the outflow of young professionals from Asia. In countries like India, Bangladesh, Pakistan, the graduate, MSc and PhD students do not have many great opportunities for growth and success. So with the dream of success they are going to the big countries in hope for a better future (Quaked, 2002)

In Albania, about one sixth of the population, including the one third that is outside are looking for work abroad (Albanian Institute for International Studies, 2005). Today, it has one of the highest rates of emigration in the world: during the 1990s, almost $40 \%$ of lecturers and scientists left the country. The teachers and researchers who remained in the Albanian institutions cited the following problems they were facing with the absence of their colleagues: reducing the competitiveness and quality of work, breakdown of research teams, reducing the motivation of researchers for long term research and focusing on short-term projects and difficulties with the transfer of knowledge and experiences from one generation to another (UNDP 2006). 
Dinkovski V., Simoska M.S.: Brain drain as a function of sustainable development in...

In Romania, scientists believe that the Government will start to fight with the problem of highly trained scientific personnel who are attracted to work abroad. According to the survey in 2002, $66 \%$ of the students in Romania most likely would like to emigrate (Tascu, Noftsinger \& Bowers, 2002). The age of the Romanian society, restrictions on industrial activities and reducing the total student population are among the most prominent negative elements of the current situation.

Bulgaria also has seen a significant brain drain (Sretenova, 2003). Many students in Bulgaria believe that there are no major negative effects from the young people leaving their country and say that this phenomenon does not have a strategic value for the state. According to the eminent magazine "Economist", every year 50,000 people leave Bulgaria. If you take that about $20 \%$ of them are with higher education, the negative impact is worsening every year with an increasing flow (Chompalow 2000).

In Serbia occasionally were published papers in which was stated that Serbia will remain without its future, and some statistics are cited concerning the outflow of personnel, on which is impossible to determine the origin and statistical basis. A figure of 600,000 personnel who left the country during the nineties is cited, but the estimate is uncertain because according to the census in Serbia from 1991, 564,304 people had higher and college education (Grecic, Kutlaca, Matejic \& Mikic, 1996).

\subsection{Impacts of brain drain on sustainable development}

The research revealed that brain drain has presented a major development constrain in terms of development opportunities and lost investment and it has drained the country of its human capital that took enormous resources to nurture and produce. The government has lost critical human capital in which it has invested resources through education and specialized training and for which it is not compensated by other nations in the region. The government has suffered a net loss because it funds the education and training of professionals who, precisely at the time they start to produce, decide to migrate.

The research further revealed that human capital is more valuable than financial capital because it is human capital that can be converted into wealth. Real wealth cannot be measured by money. One respondent responded by noting that 'money cannot teach your children but teachers can and money cannot cure the sick, but doctors can'.

Brain drain has affected both public and private consumption and investment spending. It has placed strain on government's ability to provide public services. Brain drain has significantly reduced the revenue base through decreases in incomes and corporate taxes. This has inevitably affected 
Dinkovski V., Simoska M.S.: Brain drain as a function of sustainable development in...

government's allocation for education, health, law and order. Thus, brain drain has resulted in the reduction of the quality of public services. Private investment and consumption spending has also declined as some migrants have taken along their savings and investment as they left the country.

The aim of this paper is to assess the level of brain drain and its impact on sustainable development in Macedonia and to compare the obtained results with the prevous findings in 1990 and 1994.

\subsection{Reasons for brain and "push" and "pull" factors}

The bad economic conditions are often not enough to force someone to leave the country. A great factor for leaving is the previous inefficient system and the remnants of the oligarchic corrupt structure that strives to eliminate the unwanted and unacceptable elite. When the criteria for advancement are the obedience, and not the competence, the emigration is very desirable for the oligarchy in power. On the other hand, factors that can keep a person from the risky cross-border ventures are the solved housing problems, quality of life, job security, etc. Family relationships can further influence in deciding to stay.

Table 1. Push and Pull factors

\begin{tabular}{|l|l|}
\hline \multicolumn{1}{|c|}{ „PUSH“ factors } & \multicolumn{1}{c|}{ „PULL“ factors } \\
\hline Low salaries & High salaries / scholarships \\
\hline Poor living standard & High living standard in the receiving country \\
\hline Political conditions & Family reasons (prosperity of the family) \\
\hline Lack of funds & Work in prestigious institutions \\
\hline Lack of work possibilities & Carrier advancement \\
\hline Complicated bureaucracy & Foreign languages \\
\hline Needs of monitoring & Personal contacts \\
\hline
\end{tabular}

Source: Author's

The "PUSH" factors are commonly associated with the reasons of economic nature, while in the "PULL" factors prevail the research reasons or the reasons related to career or the research.

\section{Methodology}

The study was realized based on a detailed anonymous questionnaire containing 35 questions in Macedonian and Albanian language in order to obtain a larger number of participants and a more realistic picture of the situation of brain drain among the two ethnic populations in R. of Macedonia. 
Dinkovski V., Simoska M.S.: Brain drain as a function of sustainable development in...

The survey was conducted among the students in the final year of studies from three public and two private universities: "Ss. Cyril and Methodius", "Ss. Kliment Ohridski", "Goce Delchev" and SEE University and FON University.

The questionnaire consisted of four parts. The first part of the questionnaire covered the basic biographical questions about the respondent, while the second part comprised questions about the "push / pull" factors. The third part consisted of historical data on brain drain and at the end were the migration questions from where the actual opinions of the candidate were derived.

A comparative analysis was made from three different periods (1990, 1994 and 2013). The data for the first two periods has been provided from results on the Federal project in former Yugoslavia (FP '90) and from some answers on a questionnaire from draft-project of MANU (initiated 1993).

\section{Results and Discussion}

From all respondents on the questtionnaires, 298 or $54 \%$ were women and 249 or $46 \%$ men. The mean age of subjects were 24 years (min.22, max. 27).

When asked how much students are satisfied with the quality of higher education in the country, they consider that higher education meets their requirements and they gave the following responses in 2013 (Figure 1): 42\% of them presumed that the quality of education is good, very good in $24 \%$, enough with $9 \%$ and only $7 \%$ considered that the quality of education is bad. If those results are compared to the following chart on how quality of the secondary school preparation is important for the university study, it is possible to conclude their equivalency. In the comparison made between the universities, the students from the FON University are slightly more satisfied than the others.

Figure 1. Student satisfaction with the quality of higher education in the RM.

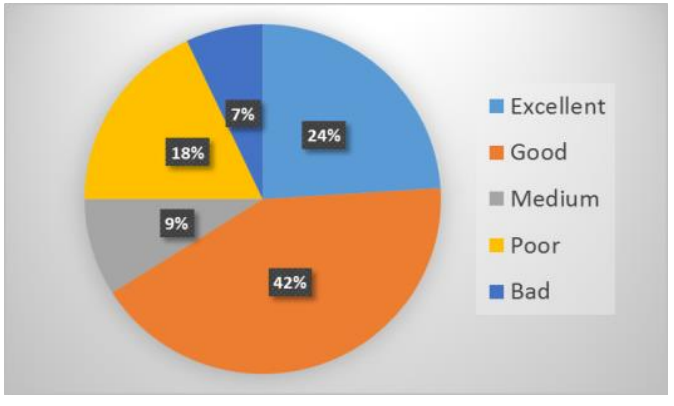

Source: Author's 
Dinkovski V., Simoska M.S.: Brain drain as a function of sustainable development in...

In Figure 2 is the research conducted in 1994, on quality of the secondary school preparation for university studies.

Figure 2. Percentages of students opinions about the quality of the secondary school preparation for university studies.

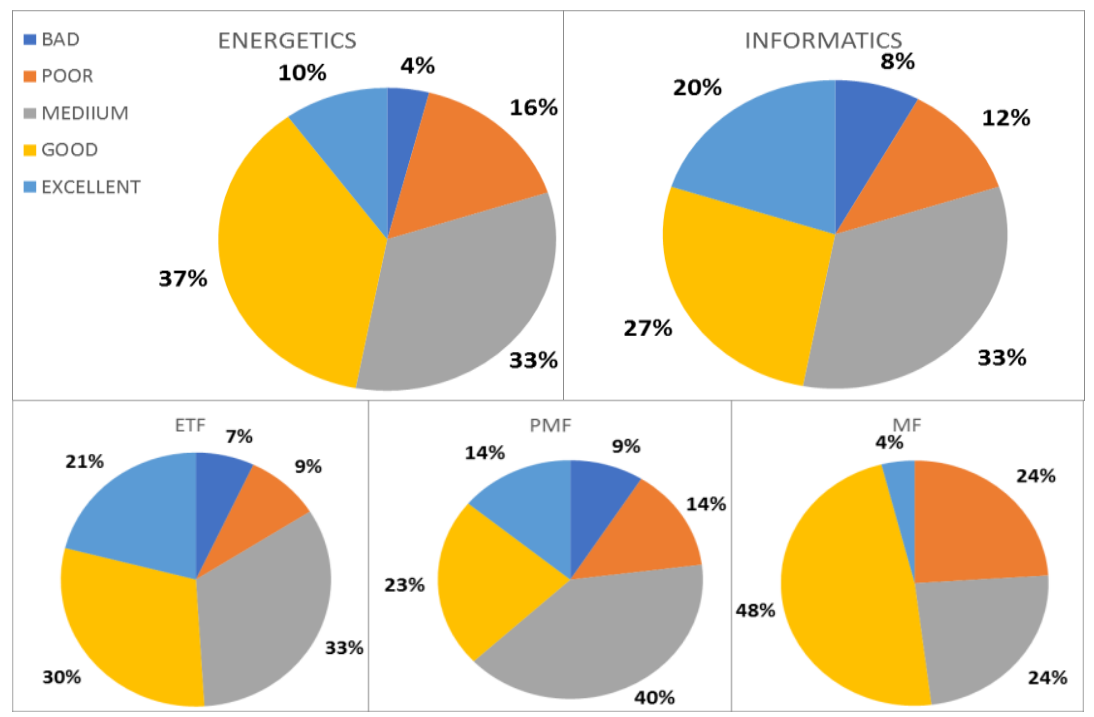

Source: (Pop-Jordanov, J. and Markovska, N. 1994)

Regarding the two periods on the same issue, 1994 and the period when this paper is prepared (2013), it can be concluded that there is no big difference between the answers of the students, even when the students are from the same or from other faculties. In all questionnaires the most used answers are good (summed $40-50 \%$ ), very good (30-40\%), etc. So, the quality acquired in the secondary education has remained the same since that period until now.

Figure 3. Answers to the question on the influence of low salaries on brain drain

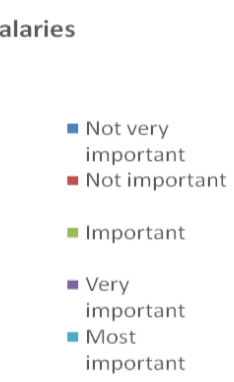

Source: Author's

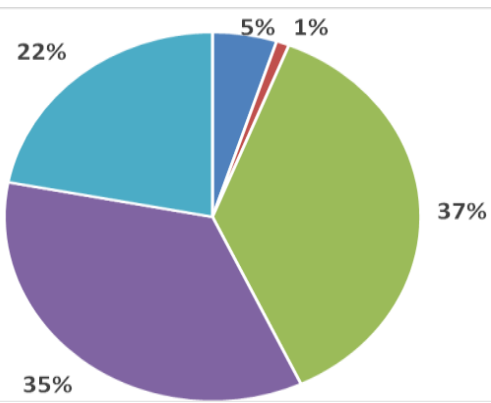

Industrija, Vol.46, No.1, 2018 
Dinkovski V., Simoska M.S.: Brain drain as a function of sustainable development in...

Regarding the question on how important are the low salaries for brain drain, the following answers were obtained: $22 \%$ answered - the most important, $35 \%$ - very important and $37 \%$ of the students answered that it is - important (Fig.3). These answers gives us the right to say, that the economic conditions have an important role.

As shown on the Fig.4 in 1994 among all factors, the leading cause for brain drain is "underestimation of professionalism", and between the faculties, the most responds of dissatisfaction of young professionals are at the Faculty of Natural and Mathematical Sciences, followed by the Faculty of Electrical Engineering and the lowest percentage of answers are at the Faculty of Mechanical Engineering.

Figure 4. Comparisons of the answers on question about the reasons for brain drain during periods (1990, 1994)

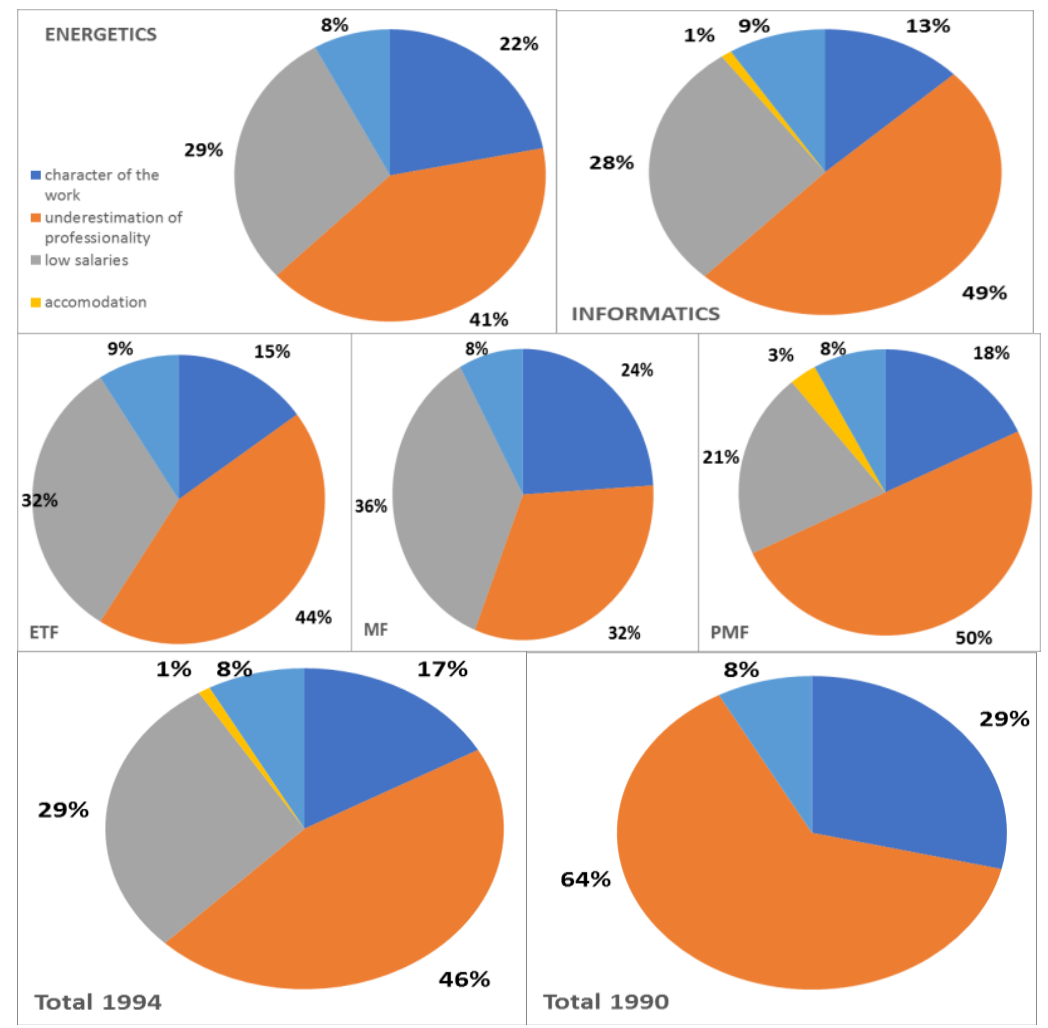

Source: (Pop-Jordanov, J. and Markovska, N. 1994) \& FP '90 (1990). 
Dinkovski V., Simoska M.S.: Brain drain as a function of sustainable development in...

If a comparison between the periods of 1990 and 1994 is made, again, the greatest reason of dissatisfaction is the underestimation of professionalism. Even more disparaging is if the results on "nature of work" as an additional professional reason are added to these results. Compared to 1990, the economic factor of "low salaries" is emerging as a second important factor for dissatisfaction.

The Figure 4 and 4.1 presents the results of the question "What are the most often reasons for dissatisfaction of young people when starting to work".

Figure 4.1 Comparisons of the answers on question about the reasons for brain drain during periods (2013)

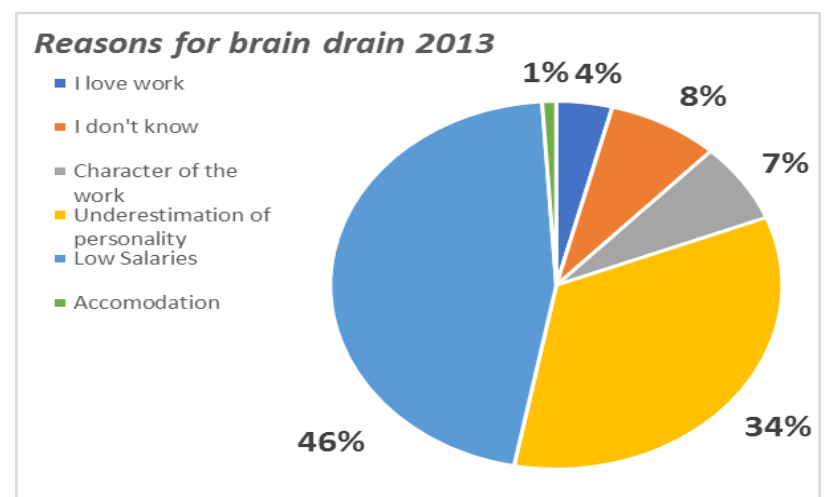

Source: (Pop-Jordanov, J. and Markovska, N. 1994) \& FP '90 (1990).

The reasons for discontent of young professionals in this period showed that unlike the periods of 1990 and 1994, in 2013 the first place reason for brain drain is the "low salaries". So, the economic factor went to the first place and thus it can be concluded that the economy regressed during the transition period.

In order to observe the tendency about brain drain, there is a question in the questionnaire "Do you think / plan to work abroad?" In the figure below it is able to see the responses of students to the survey from 1994 and from 2013.

It is evident, as it was pointed out that $80 \%$ of the students think or plan to leave the country. This is equally for electricians and IT experts at all three faculties covered. Even then it was confirmed that the situation is very difficult and alarming. It can be concluded that with respect to 1994, in the current period also prevail the responses of "I think", but also the large percentage of responses is "I plan". Could be noticed that something has changed, because higher percentage was received for answers "No" than previously $(31 \%)$, 
Dinkovski V., Simoska M.S.: Brain drain as a function of sustainable development in...

which is positive answer. Still, the situation with the other answers remains difficult.

Figure 5. Answers on question: thinking/planning to go to work abroad?

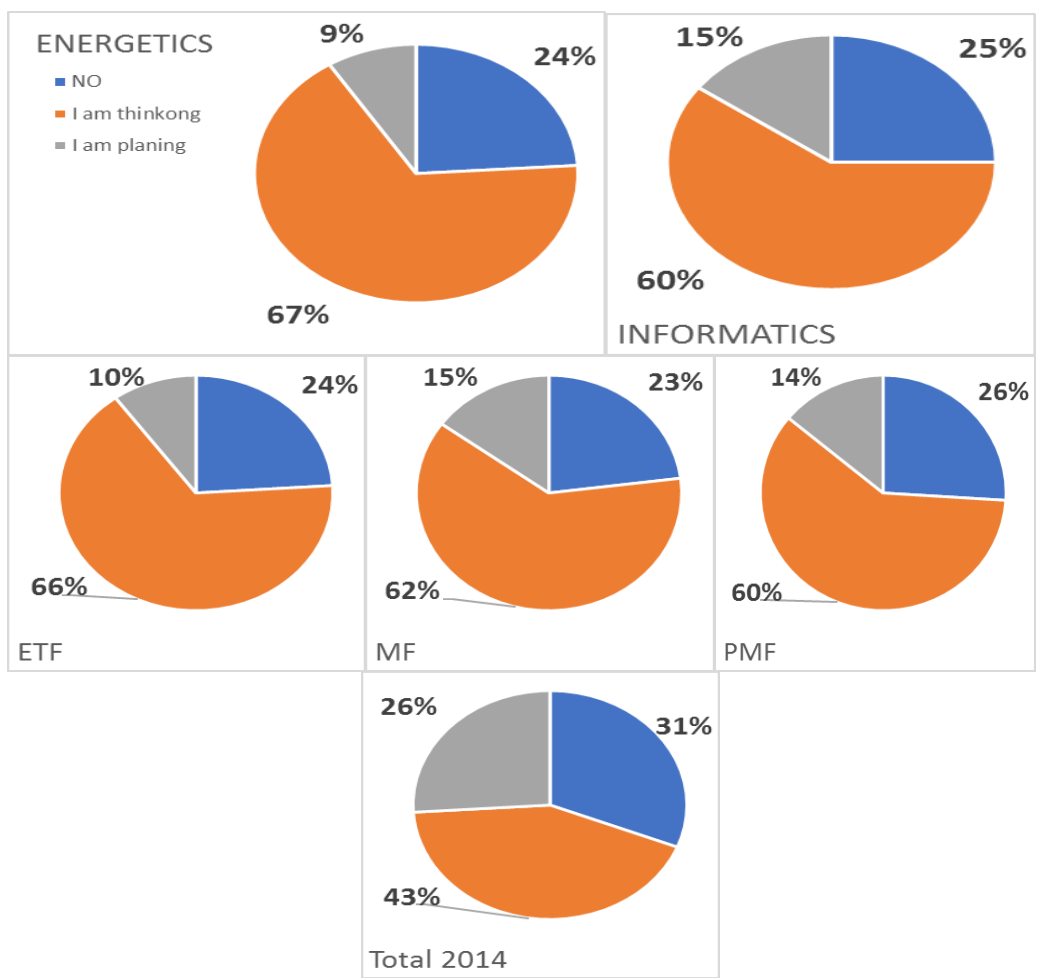

Source: (Pop-Jordanov, J. and Markovska, N. 1994)

The analysis to one of the most important issues in our research, the main reasons for brain drain are ranked in the following table 2 .

As it can be seen from the above table, the first main reason for the outflow of personnel in the country is poor incomes. The second place reason is "no work progress", followed by "political instability", "boring work", etc. So the problems of economic nature take the first place as the main reasons, according to the economy. It is important to note that only at the Faculty of Sport Education at the University of Cyril and Methodius the problems of economic nature are not at first place. Here the main reason for outflow is egalitarianism, followed by no work progress and poor incomes being on third place. 
Dinkovski V., Simoska M.S.: Brain drain as a function of sustainable development in...

Table 2. Main reason for the outflow of young people

\begin{tabular}{|c|c|c|c|c|c|c|c|c|c|c|c|c|c|c|c|}
\hline \multirow{2}{*}{\begin{tabular}{|c|} 
Universities \\
Faculties $^{*}$
\end{tabular}} & \multicolumn{2}{|c|}{ SEEU } & \multirow{2}{*}{$\begin{array}{c}\text { UCLO } \\
\text { IT }\end{array}$} & \multirow{2}{*}{$\begin{array}{l}\text { UGD } \\
\text { IT }\end{array}$} & \multicolumn{2}{|c|}{ FON } & \multicolumn{9}{|c|}{ UKIM } \\
\hline & Mac. & Alb. & & & Mac. & Alb. & \begin{tabular}{|l|} 
FEIT/ \\
FINKI
\end{tabular} & MF & TMF & FNS & FSS & Med. & Low & Ecn & $\begin{array}{l}\text { Philos } \\
\text { Philol. }\end{array}$ \\
\hline $\begin{array}{l}\text { No work } \\
\text { progress }\end{array}$ & III & V & II & II & III & III & II & II & II & II & II & II & II & II & II \\
\hline $\begin{array}{c}\text { Egalitaria } \\
\text { n. }\end{array}$ & V & VII & V & VIII & V & IV & VIIII & VI & VI & VII & I & VI & V & III & 1 \\
\hline $\begin{array}{c}\text { Poor } \\
\text { salaries }\end{array}$ & I & 1 & I & I & I & I & I & I & 1 & 1 & III & 1 & 1 & I & III \\
\hline $\begin{array}{c}\text { Political } \\
\text { instability }\end{array}$ & II & II & III & III & II & II & $\begin{array}{l}\text { I } \\
\text { V }\end{array}$ & III & VII & IV & VII & IV & III & IV & V \\
\hline $\begin{array}{l}\text { Boring } \\
\text { work }\end{array}$ & VII & VI & VIII & VII & VI & V & VIIII & IV & VIII & III & VII & VII & VI & VII & VI \\
\hline $\begin{array}{c}\text { Lack of } \\
\text { Organizat }\end{array}$ & IV & III & VI & IV & IV & VI & $\begin{array}{l}\text { II } \\
\text { I }\end{array}$ & V & IV & V & IV & III & IV & VI & IV \\
\hline $\begin{array}{c}\text { Techn. } \\
\text { inferiority }\end{array}$ & VII & VII & VII & VI & VII & $\begin{array}{c}\mathrm{VI} \\
\mathrm{I}\end{array}$ & V & VII & III & VI & V & V & VII & V & VIII \\
\hline $\begin{array}{c}\text { Limited } \\
\text { autonomy }\end{array}$ & $\mathrm{VI}$ & IV & IV & V & VIII & VIII & $\begin{array}{l}\mathrm{V} \\
\mathrm{I} \\
\end{array}$ & VIII & V & VIII & $\mathrm{VI}$ & VII & VIII & VIII & $\mathrm{VI}$ \\
\hline
\end{tabular}

Mac. - Macedonians, Alb. - Albanians, IT - Information technologies, FEIT - Faculty for electrical engineering and technology, MF- Faculty of mechanical engineering, Faculty of technology and metallurgy, FNS, Faculty of Natural Science, Faculty for Sport Education, Med F. - Faculty of Medicine, LOW - Faculty of Justice, Econ. Faculty of Economics, Philos. and Philol. - Faculties for Philosophy and Faculty of Philology

Source: Author's

In the Table 3 the main reasons for the outflow by years of research and analysis are presented.

Table 3. Ranked list of major reasons for brain drain by years of research

\begin{tabular}{|c|c|c|c|}
\hline & 1990 & 1994 & 2013 \\
\hline No work progress & II & I & II \\
\hline Egalitarianism & IV & II & V \\
\hline Poor salaries & V & III & I \\
\hline Political instability & VII & IV & III \\
\hline Boring work & III & V & VIII \\
\hline Lack of Organiz. & VI & VI & VII \\
\hline Techn.inferiority & I & VII & VI \\
\hline Limited autonomy & VIII & VIII & \\
\hline
\end{tabular}

Source: Author's

According to analyzed material, it is concluded that passing through the period of transition, the economic problem of "poor salaries" raises to first place. The professional problem of "no work progress" takes second place in almost all three periods. Given the specific situation in the region it can be 
Dinkovski V., Simoska M.S.: Brain drain as a function of sustainable development in...

noted that the political instability in the new research takes high third place, unlike other periods of research.

Figure 6. Motivation of young people (studies done in 1990, 1994, 2013)

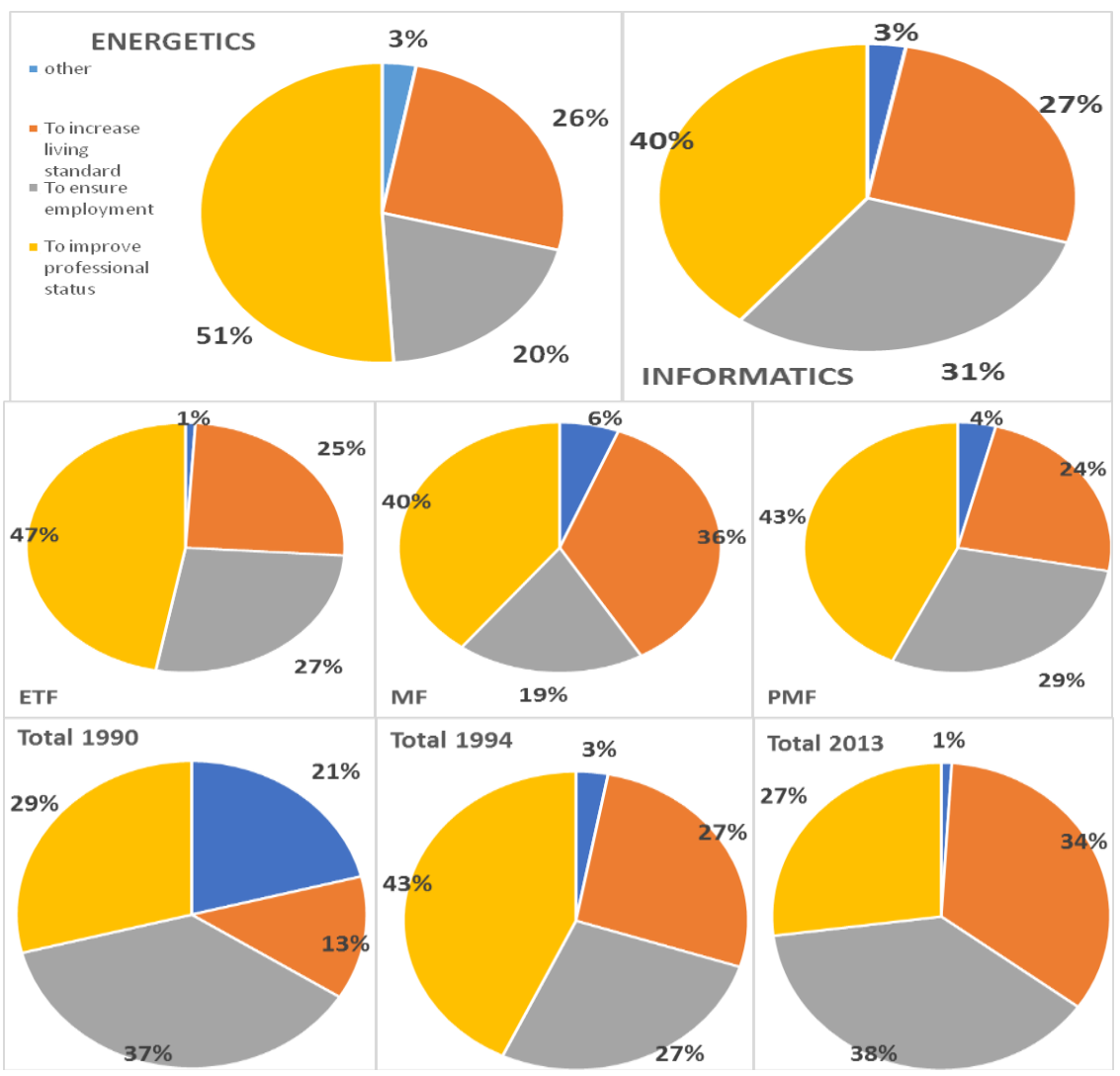

Source: Author's

The Figure 6 shows that the requirements for increasing the living standards are realistic and according to the students it is $34 \%$, unlike the previous periods, $13 \%$ and $27 \%$. The economic factors, i.e. employment, are the most important according to the students - $38 \%$ compared to the previous periods $37 \%$ and $-27 \%$. Lastly, the requirements for professionalism decline compared to the research in the last period, from $29 \%$ in 1990, $43 \%$ in 1994 and $27 \%$ in 2013.

Of the remaining, the most concerning answers are the political reasons, i.e. to reduce the political divisions, not to have political influence in work places, reducing the corruption, overhauling of the system, etc. A number of students 
Dinkovski V., Simoska M.S.: Brain drain as a function of sustainable development in...

reported for: better functionality of companies, smaller difference between economic classes, etc.

\section{Conclusiion and Recommendations}

From the conveyed survey it can be concluded that, unlike the past periods, where the main reasons for the outflow were the professional ones, in the current research obtained results indicate that the main reasons for the brain drain are from economic nature, i.e. poor earnings, low salaries. According to these reasons, young students are forced to seek a way out of the country, and if both responsive answers "I plan / think" are combined, a response percentage of $69 \%$ for and $31 \%$ against is received to the question "Would you leave the country". If a comparison to the last research is made, it's possible to perceive that the answers have an approximate percentage of $60 \%$ according to which it's feasible to conclude that in the transition period, the country's economic situation became worse, given that the main reason is small salary.

Taking in consideration the conclusions of the previous and current research, the situation of brain drain in the country is alarming.

How is the situation now? There are no significant changes.

In the current research, $69 \%$ of asked students surveyed said they think or plan to work abroad. But now the reasons are more economic in nature. To what extent the economic reasons play a role in our situation shows the fact that at the FON University the students of Macedonian nationality answered negatively to the question of leaving the country by $58 \%$. This is taken into account because it is considered that the mentioned university enrolls students with a better financial situation. It is also important to note that at the same university, on the same question, the Albanian students responded with the same high percentage of non-leaving the country as the students of Macedonian nationality.

With the entry of the Republic of Macedonia in the process of transition, the problems in education have begun to rise. The economic transformation has led no only to reduced demand for certain educational profiles, but has also caused more profound structural disproportions between the output of the educational system and the demands of the labor market. The recession, especially in the construction and manufacturing industry, lead to reduced demand for secondary and higher education profiles from the technical, technological and mechanical profiles. On the other hand, it caused a significant degree of unused capacity, i.e. of the physical infrastructure and of the teaching staff in these profiles of the secondary and higher education. 
Dinkovski V., Simoska M.S.: Brain drain as a function of sustainable development in...

It is also of concern the small number of scholars engaged in the research and development units of the companies. In general, the poor conditions in the economy are sufficient motivation for existing management teams to invest in research and development activities.

According to statistical indicators (NBRM Statistics, 2012), all the listed problems are due to the financing of research in the Republic of Macedonia for the past years. There has been a continuous reduction in the number of employees in the research activity. From the above data can be seen that for only 15 years (from 1997 to 2009) the number of these employees has been reduced by $23 \%$. It is worth noting that, with some minor oscillations, also in the business sector the number of employees is reduced, and in 2009 it was only $3.3 \%$ of the total number employed in research activities. This trend is worrying and points to the small interest of the business sector for research activities.

Undoubtedly, the human resources are unavoidable factor in the creation of the development of science and without the necessary number of quality scientists it is hard to talk about progress in the research activity, and thus for the overall development of the country.

Unfortunately, during the transition period, because of several reasons, the scientific research did not give the expected contribution to the economic development of the Republic of Macedonia. Several programs and strategies were adopted, but they did not bring some improvements or changes. It is apparently due to the poor implementation, untrained staff, old habits or other reasons, but a great benefit hasn't been achieved. Brain drain plays a negative role in the efforts toward sustainability and capacity building.

It is a fact that young professionals need to advance in their jobs. In the nature of their professional development is to travel to institutions of some countries where they would specialize in their profession. Certainly, the professional and economic conditions and the political situation between the countries in transition and developing countries contribute to the process of brain drain. The mobility should be encouraged and the brain drain to be prevented or transformed into "Brain gain" (Gailard and Jacques, 2001). A question emerges: What has to be done to prevent it? Conditions should be made for the investigator not to leave, but to go and to return. In order to get this, everything needs to be done to attract the staff to return back by creating an atmosphere of safety and comfort for quality research and providing good and new jobs, among other measures, such as solving housing issues, investment in equipment, literature access, and of course a positive valuation of the effort. To the returned scientists need to be given in our society a special status of top scientists, thus giving an example of how the native country takes care of those who have returned back. 
Dinkovski V., Simoska M.S.: Brain drain as a function of sustainable development in...

If are considered the results of the questionnaire, and the facts stated above, it should be done something to keep the staff in our country. It can be seen that there are initial steps, and the Government, higher education institutions and the businesses community need to do their part. To increase their cooperation, the teams should be formed and to launch concrete projects according to a specific program and strategy. The Government through the Ministry of Education and Science and the Ministry of Labor and Social Policy to continue to implement the ongoing projects and to apply for new. To involve therein people who know the issues and to systematically solve tasks. According to the survey, the issue on which the students are the most dissatisfied - opening new jobs can be gradually solved by improving the economic policies, increasing the percentage of funds allocated from the budget for research, science and education, thus conditions would be created for work as in the more developed countries.

In addition, the Diaspora needs to be involved. If a good coordination between our higher education institutions, the economy and the clubs in the Diaspora, is made, for a small amount of funds good projects could be made. A network of experienced and professional scientists should be established, in the country and the Diaspora, of who it would be expected to encourage initiatives, professional spirit and contacts.

It should be noted that the Government should pay a great attention to the issue of political job hiring, which is the major concern of the most of the young staff. If the situation will continue with the same pace and practice, then surely the brain drain will be higher. Understanding that science is an indispensable factor for the development of the country, and thus of the economy, then should be allowed competition to take its place in the education and science based on international and global priorities for the development of humanity. Building a sense of a secure and competitive society, where the competence would be respected, will ensure young scientists to find their selves in the developed world.

Until now there was no clear strategy on how the brain-drain can be transformed into brain circulation, it will be addressed by the new Brain-drain Strategy for the period 2013-2020. The strategy is currently being developed on behalf of the Ministry of Education and Science.

\section{References}

Slaus, I., Pop-Jordanov, J., \& et al., (1993). Conclusions. WG CFE / Club of Rome. November.

-International Organization of Migration (IOM). (2007). Country profile: Macedonia. Ljubljana. 
Dinkovski V., Simoska M.S.: Brain drain as a function of sustainable development in...

Mahroum, S. (2001). Europe and the Immigration of Highly Skilled Labour. International Migration, 39(5), 27-43. doi:10.1111/1468-2435.00170

Horvat, V. (2004). Brain Drain. Threat to Successful Transition in South East Europe. Southeast European Politics, Vol. V, No. 1, pp. 76-93.

Coombes, R. (2005). Developed world is robbing African countries of health staff. BMJ, 330(7497), 923-923. April 23. doi:10.1136/bmj.330.7497.923-b

-Albanian Institute for International Studies. (2005). Albanian Brain Drain: Turning the Tide. Tirana.

-UNDP. (2006). From Brain Drain to Brain Gain: Mobilizing Albania's Skilled Diaspora. Tirana.

Tascu, M.V., Noftsinger, J., \& Bowers, S. (2002). The Problem of Post-Communist Education: The Romanian Example. The Journal of Social, Political and Economic Studies, Vol. 27, No. 2, pp. 203-226.

Sretenova, N. (2003). Scientific mobility and 'brain drain' issues in the context of structural reforms of Research \& Development and High Education Sector in Bulgaria, Report: Symposium on Science Policy, Mobility and Brain Drain in the EU \& Candidate countries. available at: www.leeds.ac.uk/law/cslpe/phare/No.2.pdf..

Chompalov, I. (2000). Brain Drain from Bulgaria Before and After Transition to Democracy: Bulgarian Research Symposium and Network Meeting, Atlanta.

Grečić, V., Kutlača, Đ., Matejić, V., \& Mikić, O. (1996). Migracije visokostručnih kadrova I naučnika iz SR Jugoslavije. Beograd: Institut za međunarodnu politiku i privredu / Ministarstvo za razvoj, nauku i životnu sredinu.

FP '90: Federal Project Policy and measures concerning brain drain from Yugoslavia. (1990).

Pop-Jordanov, J., \& Markovska, N. (1993). Brain Drain in Energy and Informatics. Encyclopaedia moderna, XIV, 4(44), 308-313.

-Народна банка на Република Македонија. (2012). Статистика, Основни економски показатели. www.nbrm.gov.mk.

Gaillard, A., \& Jacques, M. (2001). Brain Drain to Brain Gain. UNESCO Sources, 132, p. 4-6. (www.unescosources.org).

(2012). Скопје. http://www.euraxessmanual.com/handbook-presentation/the-webhandbook.

-Национална агенција за европски образовни програми. Национална агенција за европски образовни програми. www.na.org.mk.

Поп-Јорданов, Ј. (2002). Инженерската наука како решавачки фрактор за одржлив развој: Прв конгрес на инженерите на Македонија, 24-26 октомври, Струга. стр. 14-19. 